\title{
1 \\ Beginning with an idea - Warby Parker: revolutionizing the way eyeglasses are sold and social entrepreneurship is carried out
}

http://www.warby-parker.com/

\section{Donating can create dependencies. Therefore, it is important to not donate but support poor people in order to create business structures. ${ }^{1}$}

With this statement, the founders of Warby Parker disrupted the traditional social entrepreneurship model of "buy-one, give-one" by launching the company in 2010. By 2020, the co-CEOs, David Gilboa and Neil Blumenthal, had achieved a value of $\$ 1.7$ billion for the company and expanded their initial exclusive operations of selling eyeglasses on the internet to include 90 physical stores in the United States and Canada. With such success for their business, the CEOs knew they would have to continue to innovate to stay one step ahead of the copy-cat eyeglass competitors.

\section{BACKGROUND ON WARBY PARKER}

In the summer of 2008, David Gilboa was backpacking around the world before he started to graduate school. Unfortunately, he lost his glasses on a plane and delayed buying a pair in his first semester in school because eyeglasses were so expensive. He found it hard to believe that he could buy a new phone for $\$ 200$, but a pair of designer glasses cost $\$ 700{ }^{2}$

Gilboa and Blumenthal and the two other founders, Andrew Hunt and Jeffrey Raider, were all students at the Wharton School at the University of Pennsylvania, and they began kicking around an idea for an online operation that would sell inexpensive yet stylish eyeglasses. One of the founders sent around a three-page email about the business idea, and the other three responded to it.

Before long, each of the founders had taken the lead on some part of the operation. Gilboa built the website, set up the supply chain, hired the first employee, set up a phone system and a customer service system. Blumenthal worked on branding and drew up a mission and values statement. The founders utilized focus groups in the beginning to determine if the idea for the 
business would capture the attention of their potential customers. They were trying to understand the business model of Luxottica and the other large optical retailers. Each of the founders put in $\$ 30,000$ for the startup of the business. The company was launched in 2010 while all four of the founders were still in school. ${ }^{3}$ The venture also received $\$ 2,500$ as seed money from The Venture Initiation Program at the Wharton School. The name Warby Parker was derived from two characters in a novel by Jack Kerouac-Warby Pepper and Zagg Parker.

The founders chose JAND Inc. as their corporate name. Because of their low price point and classy product, the company surpassed their first year's sales target within three weeks after launch. The business sold out of its top 15 sellers in just four weeks and had a waiting list of 20,000 names. All of this was accomplished without any paid advertising. ${ }^{4}$ By May of 2011, the company had shipped more than 100,000 pairs of glasses and had 60 employees. By the end of 2012, the company had expanded to 100 employees.

\section{BACKGROUND ON GILBOA AND BLUMENTHAL}

\section{David Gilboa}

Gilboa was born in Sweden, and his parents were both doctors. When he was a teenager, David would often go with his father to the hospital to learn all that he could about medical specialties. At the time, he intended to study medicine and become a doctor. However, when he was a premed student at the University of California, Berkeley, he found out about HMOs and that led to a decision to seek another career. After leaving medical school, he worked for Bain Capital and later for the investment bank Allen \& Co. He later returned to school at the University of Pennsylvania to get a master's degree in biomedical engineering and an MBA at the Wharton School. It was there that he met the other co-founders of Warby Parker. Blumenthal referred to him as "the smart one."5

\section{Neil Blumenthal}

Blumenthal was the son of a tax consultant and a nurse. He grew up in Greenwich Village and had always had an entrepreneurial streak. When he was only 8 years old, he convinced his parents to buy him a food dehydrator so that he could begin a dried fruits stand on Mercer Street. In high school, he was a club promoter at a local night club.

Blumenthal attended Tufts University and had a double major in international relations and history. At this point, he wanted to be the Secretary of State of the United States. After college, he had a fellowship in El Salvador and helped develop the market-based approach to philanthropy at VisionSpring. Blumenthal suggested, "I was trying to understand how we could get entrepreneurs to spend more time selling glasses, doing margin analysis, going over to China to try to source glasses at lower cost." ${ }^{\prime 6}$ All of these experiences prepared him for his work at Warby Parker. 


\section{MISSION}

The mission of Warby Parker is to offer designer eyeglasses at a revolutionary price, while leading the way for socially conscious businesses.

\section{VALUE PROPOSITION}

The company vows to offer low price but high quality that can be achieved by vertical integration and cutting out the middleman. They design the glasses in-house and sell them directly to the customer.

\section{THE PRODUCT}

One of the initial problems the CEOs ran into was the issue of customers not being able to try on their products since they were buying them on the internet. To get around this challenge, the company decided to send each customer five pairs of frames to try on and select a favorite design. The customer was required to return the glasses within five days. This convenient option did not have a charge attached to it so it allowed a customer to try on the frames at home just as they would in the store. Some of their eye wear sold for as little as \$95. By the establishment of this process of selling inexpensive glasses online, Warby Parker became a disrupter in the eyeglass industry (see Figure 1.1 entitled "Eyeglasses" and Figure 1.2 entitled "Sunglasses.")

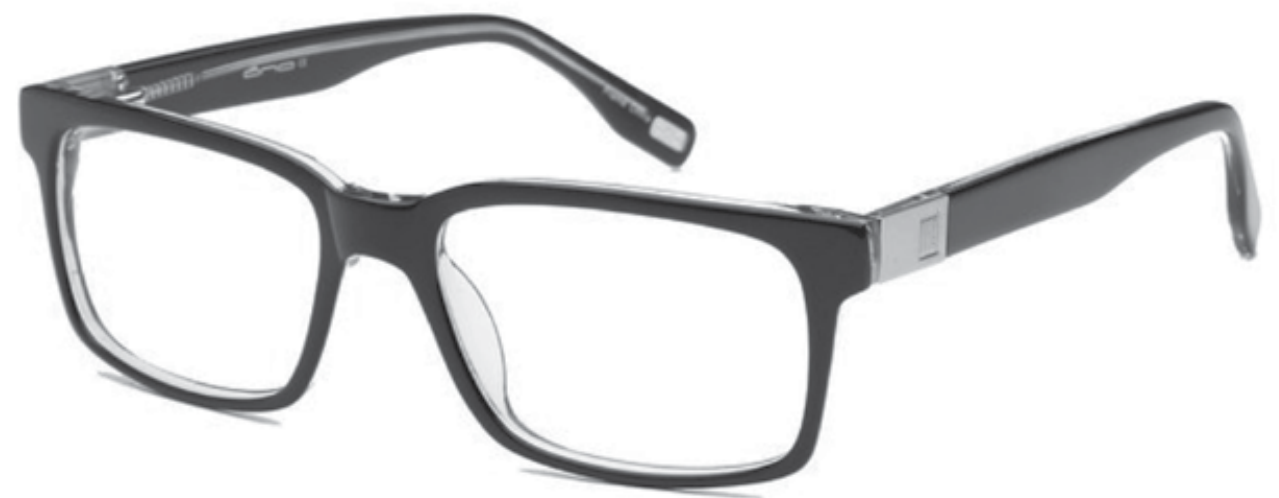

Source: This photo by unknown author is licensed under CC BY-SA; this license is free by the licensor.

\section{Figure 1.1 Eyeglasses}




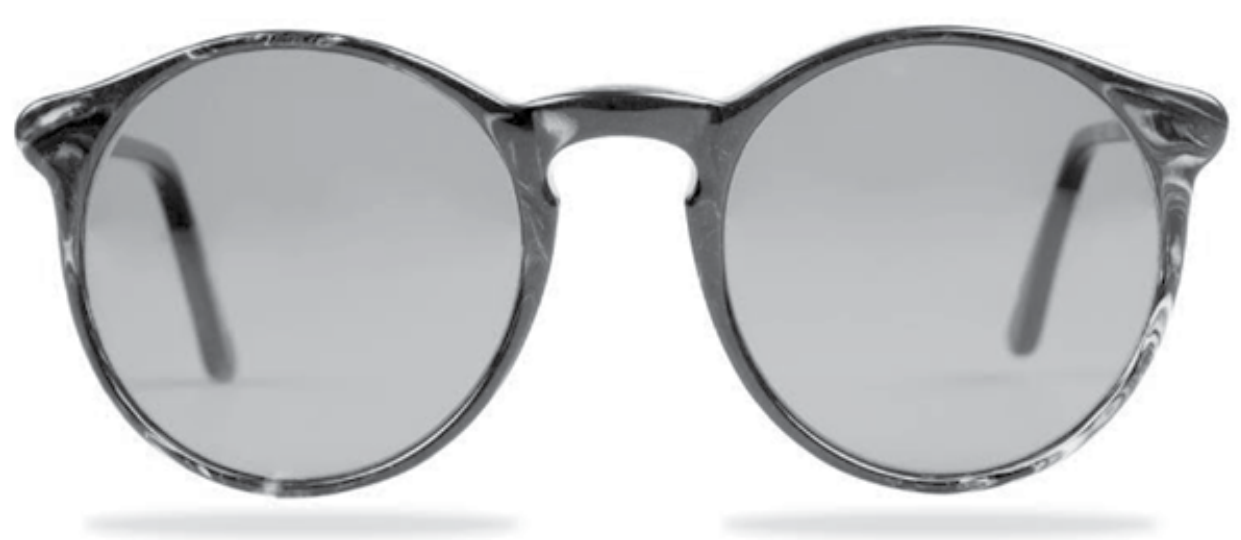

Source: This photo by unknown author is licensed under CC BY-NC-ND; this license is free by the licensor.

\section{Figure 1.2 Sunglasses}

\section{Copy-cats}

The business model adopted by Warby Parker was very easy to replicate. The process had been followed by companies selling products from mattresses to men's shoes. There were a few companies that were complete copy-cats and did everything that Warby Parker did. These companies were EyeFly, Made Eyewear, and Jimmy Fairly. However, even though they had adopted the business model of Warby Parker, they had not received the attention and the sales of this company. Joel Cutler, a co-founder of the venture firm General Catalyst Partners and an investor in Warby Parker said, "Neil and Dave are inventing this idea of what a technology-based lifestyle brand is."

\section{Outsourcing}

David Gilboa suggested that the best advice he could give about the development of a product was to never outsource critical components of your business. In supporting that advice, he said:

None of us were qualified to build the website, so we solicited proposals and got a handful of bids from agencies. We chose the cheapest option, but a few months in, we realized that it was a mistake. Their execution wasn't what they promised, so we fired them. ${ }^{8}$

After that experience, they decided to develop all of their technology within the company to give the customer the best possible experience.

The company ordered its own materials from Italy, and one of the biggest inputs for the glasses was acetate. Originally, they had their glasses manufactured in China, but in 2017 they opened an optical lab in Rockland County, New York, in order to produce their own glasses 
and ensure the quality that they desired. The lab contained 34,000 square feet and employed 130 people.

Not all CEOs believed that the smartest way to run a company was to avoid outsourcing. Debra Cohen, founder of Home Remedies of New York, a home improvement contract referral service, outsourced all of her operations. She had only one employee, and Cohen concentrated on sales, business development, and screening home improvement vendors. Even her web development and maintenance, graphic design, software development, and financial record keeping were outsourced. Cohen suggested, "Stick to what you are good at and outsource everything else."

\section{Employees}

To preserve the free-wheeling spirit of the founders, when potential employees were interviewed, they were asked, "When was the last time you wore a costume?" After they were hired, the employees area asked to fill out a "15 Five" report every week explaining what they accomplished in the past week, their plans for the coming week, and a suggestion for an innovative idea. The model for hiring employees at Warby Parker was not Zappo's but Bain Capital. The employees for their call center were hired directly out of college and were expected to answer phone calls for a couple of years before rising within the organization. ${ }^{10}$ Since eyeglasses were high-grossing products, the company was able to pay their call center employees well.

All of the new employees at Warby Parker were given a copy of Jack Kerouac's book entitled The Dharma Bums and a copy of the Style Guide which included suggestions about usage and grammar. The Guide also encouraged employees, when they communicated with customers, to write like Warby Parker was the person you'd want to be next to you at a dinner party. ${ }^{11}$

\section{E-COMMERCE VS. BRICK-AND-MORTAR STORES}

Warby Parker opened its first brick-and-mortar store in 2013 after launching their products online in 2011. The intention of the company was to further develop their brand with the retail stores. In 2015, they extended their brand further by partnering with Nordstrom to develop "pop up shops" around the country.

Sucharita Mulpurn, a retail analyst, suggested that since 90 percent of retail still takes place in brick-and-mortar stores, this decision by Warby Parker made a lot of sense. She further explained:

There's an argument that when you're a private label and people don't necessarily know who you are, letting them touch and feel your products can be critical in reducing any friction. $^{12}$

Neil Blumenthal sees the future of retailing as a convergence of brick-and-mortar and e-commerce. In order to serve their customers more efficiently, they came up with a procedure by which customers could book an appointment online to have an eye exam. Then when they 
entered the store, they would see a large digital screen that displayed the time of the appointment. The screen was fashioned after train station boards with updates every 15 minutes. ${ }^{13}$

\section{THE EYEGLASS INDUSTRY}

This industry produces eyeglasses, contact lens and sunglasses.

One of the key drivers is the aging population because as people get older they tend to need corrective lenses. Another driver is funding by Medicare and Medicaid and private insurance. Whenever there is an increase in federal funding for Medicare and Medicaid, the demand for corrective lenses also increases. Federal funding for these two programs was expected to increase in 2019. The growth in the number of people covered by private health insurance was expected to slow in the next few years following 2019.

An increase in per capita disposable income allows people to spend more money on items that are not essential such as eyeglass frames. Growth in disposable income was expected to increase in 2019. Eyeglass and contact lens manufacturing contracted over the five years leading to 2019. Some of the reasons for this slowed performance was the strength of the dollar which boosted the importation of glasses from abroad. However, with the increase in disposable income, and private health insurance coverage, consumers have been visiting optometrists more frequently, resulting in greater demand for these products. To remain competitive, American producers have had to alter their business strategies to meet the increase in imports.

After suffering from years of decline, revenue growth in the United States increased 0.20 percent in 2018 and 2.0 percent in 2019. The outlook was for zero growth in revenue in 2020 and above 1.0 percent growth in 2021 and $2022 .{ }^{14}$

\section{LUXOTTICA}

This vertically integrated Italian company designed as well as manufactured eye wear. By 2019, the company had a 40 percent market share in the eyeglass industry. Luxottica operated in 150 countries and 8,000 retail locations. The company's primary retail operations were LensCrafters and Pearle Vision chain stores. In its sunglass division, the company operated through the Sunglass Hut and Oakley stores. The primary focus of operations of the company was in the mid- to premium-priced eye wear. The leading house brand was Ray-Ban, but they also offered glasses under the name Prada, Dolce \& Gabbana, Polo Ralph Lauren and Chanel.

In the years leading up to 2019, the company had concentrated on reducing their costs, closing underperforming stores and refining their product portfolio to move into higher-end offerings. However, the mid- and premium-priced categories were vulnerable to consumer preferences and economic downturns. ${ }^{15}$ 


\section{THE SOCIAL ENTREPRENEURSHIP MODEL}

The founders of Warby Parker resisted following the traditional "buy-one, give-one" model made famous by Tom's Shoes. With this model, each time a customer bought a pair of shoes from Tom's, the company supplied a second pair of shoes for someone in need-normally in a Third World country. The problem with this model was that this cut out many entrepreneurs selling shoes in the country in which the shoes were furnished. Thus, a backlash was created in the country against a company that was hurting the development of small businesses.

Warby Parker altered this approach to social entrepreneurship by setting up a program whereby when a pair of glasses was purchased from their company, they would pay for the production of another pair of glasses for the non-profit organization VisionSpring. Then VisionSpring would sell the glasses to companies in developing countries so that entrepreneurship would be supported in that country. The social entrepreneurship portion of their mission was added when the founders discovered that approximately 10 percent of the world's population needed glasses but did not have them. VisionSpring also trained low-income entrepreneurs to sell the glasses in their villages.

Another part of their social entrepreneurship program was the Pupil Project. Such dignitaries as Gloria Steinem and Iman designed some of the glasses used in the program. The Pupil Project furnished screenings, eye exams, and attractive glasses to students who could not afford a pair on their own. David Gilboa said of the project, "There's nothing like watching these students, many of whom are getting their first pair of glasses, finally see the board clearly."16

The famous model Iman decided to participate in the program because she speculated, "So often we take the gift of sight for granted. We just assume that when we hone in on something, it will come through with crystal clarity. However, when we need to improve our vision, it often comes with a price that is virtually unaffordable to most."17

The project by 2018 had already delivered 46,000 pairs of glasses to 150 public elementary and middle schools in Baltimore.

Normally a social entrepreneur is defined as one who aspires to have a double bottom line. In other words, along with the pursuit of a positive financial bottom line would be the pursuit of another bottom line that supports some social cause. Observers often wonder if it is the financial bottom line that takes precedence over the social bottom line or just the reverse.

J. Gregory Dees, a researcher in this area, suggests that his research suggests the proposition that the social mission is the most important criterion to most social entrepreneurs. $\mathrm{He}$ believes that wealth, the financial bottom line, is a means to an end for most who follow a social mission. $^{18}$

On the other hand, there are those researchers who look at social entrepreneurship along a continuum. At one extreme would be those social entrepreneurs who are driven solely by social benefits. At the other end of the spectrum would be social entrepreneurs who are driven by profitability with social benefits being the means to the end. ${ }^{19}$ 


\section{THE FUTURE}

In an interview with Fortune magazine, Neil Blumenthal in commenting on the disruptive nature of the Warby Parker model suggested, “The best businesses solve real problems. We've created an example of a business that can scale, be profitable, and do good in the world without charging a premium." 20

What lies ahead for the company? One can only speculate about the uncharted waters that Gilboa and Blumenthal might explore.

\section{NOTES}

1. Warby Parker Business Model Toolbox. https://bmtoolbox.net/stories/warby-parker/. Accessed June 21, 2019.

2. Eng, Dinah (May 30, 2019). In hindsight: How Warby Parker got its start, Fortune. http://www.fortune.com/ 2019/05/30/warby-parker-founders/. Accessed August 1, 2019.

3. Ibid.

4. Building momentum in men's wear (April 5, 2012). WWD, 2b. Academic OneFile. http://link.galegroup.com/ apps/doc/A286522382/AONE?u=txshracd2488\&sid=AONE\&xid=2f7f1c2d. Accessed July 15, 2019.

5. Chafkin, Max (February 17, 2015). Warby Parker sees the future of retailing. Fast Company. https://www .fastcompany.com/3041334/warby-parker-sees-the-future-of-retailing. Accessed July 15, 2019.

6. Ibid.

7. Chafkin, Max (February 17, 2015). Warby Parker sees the future of retailing. Fast Company. https://www .fastcompany.com/3041334/warby-parker-sees-the-futre-of-retailing. Accessed July 15, 2019.

8. Eng, Dinah (May 30, 2019). In hindsight: How Warby Parker got its start. Fortune. http://www.fortune.com/ 2019/05/30/warby-parker-founders/. Accessed August 1, 2019.

9. Girard, Keith (December 6, 2005). Small business borrowing strong. Daily News Digest. http://www .allbusiness.com/news/daily_news.asp?ID=11430\#11431. Accessed August 18, 2019.

10. Chafkin, Max (February 17, 2015). Warby Parker sees the future of retailing. Fast Company. https://www .fastcompany.com/3041334/warby-parker-sees-the-future-of-retailing. Accessed July 15, 2019.

11. Eng, Dinah (May 30, 2019). In hindsight: How Warby Parker got its start. Fortune. http://www.fortune.com/ 2019/05/30/warby-parker-founders/. Accessed August 1, 2019.

12. Bazilian, Emma (April 22, 2013). Adweek, 54, No. 16, p. 20.

13. Grobant, Sam (August 12, 2013). Neil Blumenthal, co-CEO, co-founder Warby Parker. Bloomberg Businessweek, Issue 4342, p. 83.

14. IBISWorld (July 2019). Glasses \& contact lens manufacturing in the U.S. https://www.Ibisworld.com. Accessed July 18, 2019.

15. Ibid.

16. Holgate, Mark (October 5, 2018). Warby Parker's latest collaboration not only benefits schoolkids, it will have you seeing stars. Vogue. https://www.yahoo.com/lifestyle/warby-parker-latest-collaboration-not -180000786.html. Accessed August 5, 2019.

17. Ibid.

18. Dees, J. Gregory (1998). Enterprising nonprofits. Harvard Business Review, 76, No. 1, 54-67. 
19. Peredo, Ana Marie and Chrisman, James J. (2006). Social entrepreneurship: A critical review of the concept. Journal of World Business, 41, No. 1, 56-65.

20. Eng, Dinah (May 30, 2019). In hindsight: How Warby Parker got its start. Fortune. http://www.fortune.com/ 2019/05/30/warby-parker-founders/. Accessed August 1, 2019.

\section{REFERENCES}

Bazilian, Emma (April 22, 2013). Adweek, 54, No. 16, p. 20.

Building momentum in men's wear (April 5, 2012). WWD, 2b. Academic OneFile. https://link.galegroup .com/apps/doc/A286522382/AONE?u=txshracd2488\&sid=AONE\&xid=2f7f1c2d. Accessed July 15, 2019.

Chafkin, Max (February 17, 2015). Warby Parker sees the future of retailing. Fast Company. https://www .fastcompany.com/3041334/warby-parker-sees-the-future-of-retailing. Accessed July 15, 2019.

Dees, J. Gregory (1998). Enterprising nonprofits. Harvard Business Review, 76, No. 1, 54-67.

Eng, Dinah (May 30, 2019). In hindsight: How Warby Parker got its start. Fortune. http://www.fortune .com/2019/05/30/warby-parker-founders/. Accessed August 1, 2019.

Girard, Keith (December 6, 2005). Small business borrowing strong. Daily News Digest. http://www .allbusiness.com/news/daily_news.asp?ID=11430\#11431. Accessed August 18, 2019.

Grobant, Sam (August 12, 2013). Neil Blumenthal, co-CEO, co-founder Warby Parker. Bloomberg Businessweek, Issue 4342, p. 83.

Holgate, Mark (October 5, 2018). Warby Parker's latest collaboration not only benefits schoolkids, it will have you seeing stars. Vogue. https://www.yahoo.com/lifestyle/warby-parker-latest-collaboration-not -180000786.html. Accessed August 5, 2019.

IBISWorld (July 2019). Glasses \& contact lens manufacturing in the U.S. https://222.ibisworld.com. Accessed July 18, 2019.

Peredo, Ana Marie and Chrisman, James J. (2006). Social entrepreneurship: A critical review of the concept. Journal of World Business, 41, No. 1, 56-65.

Warby Parker Business Model Toolbox. https://bmtoolbox.net/stories/warby-parker/. Accessed June 21, 2019. 